\title{
第14回学会 シンポジューム（I）
}

\section{胸椎 の撮影について}

富士製鉄株式会社室蘭製鉄所病院

古行鉄 雄

\section{緒言}

会長の御指名で本題のシンポデュームの演者の一員に 選ばれまして光栄に存じます．実はこの分野に御造詣の 深い方々が打られますし，一作業所病院で㭧者数も少な く充分の成果も期待出来ませんので躊踫いたしましたが この機会に本撮影法の一部に海検討を加えることる意義 あることと思い厚顔にも御引受けいたした次第です。

胸椎の撮影中で上部胸椎側面は診断し易い写真を得る ここは非常に困難で従って本題の重点は上部胸椎側面で あろうと考えます。

腳椎には各種の陰影が重畕しますのでてれらを取り のぞく方法としまして私の識って抢ります極く狭い範 囲では1949年に K. C. Clark 氏1)，1950年に Geraldo Guerreiro 氏 22)が呼吸時撮影について言及しておられま す.

わが国では1952年（昭和27年）北海道の草皆太平君が 呼吸時撮影法を追試し本学会雑誌に発表していられます。

別の庁法こしましては米沢市三友堂病院の浦山晴一先 生は昨:年 7 月発行の整形外科雑誌に断圓撮影による厚層 撮影について発表していられます

私は草皆君が行いました頃と現在に比較しましてX線 管焦点力渄常に小さくなり，堌感紙の解像力う向上しX 線写真も極めて鮮鋭よなり呼吸による極く微かな動きも 観過され難いので掂大撮影とともに再検討を加えること と，断首撮影装置による厚層撮影の追試をいたしました ので御報告申し上げます。しかし応用例か誠に少なくこ の点古分の自信虑持てませんが何等かの御参考になれば 幸㝴と存じすす。

\section{従来の一般的撮影法の短所}

現在一般に行われております胸椎側面撮影法は側卧位 で㓐を曲げ有を出来るだけ後方に引き，手を背で組むか あるいは両上肢を挙上する体位で撮影時呼吸を停止させ るのであります。
立位で同様の体位による撮影もありますが体固定用具 の完壁な用意が汁ればなりませんし安定度からしても 仰卧位より優れたものとは考觉られません。

その他斜位撮影においても補肋用具を使用しない場合 安定な体位でなく従って呼吸停止により体動摇を防止し ているとも考えられます。

てれらの方法で撮影された写真は胸椎像とともに敛骨， 助骨, 肺紋理即古石灭化像, 気管支像, 肺門淋巴腺像, 肺動静脈像等数多くの陰影が重畳し診断に著しい障害を 与えております。

\section{撮影装置, 使用用品および改造部}

撮影装置，使用用品は別表 Iに示す通りですが，X線 発生装置 KX-13 は 20 年前に購入した単相半波整流装置 で現在は整流管をトリウム，タングステン整流管 K $41 \mathrm{~S}$ にし管内電圧降下を少なくし，X線管，整流管加熱変圧 器は鉄共振型電圧安定琶置を使用しました。

特型 500 は A 型断層撮影装置之組合わせ名転陽極 $\mathrm{X}$ 線 管 DRX-70（この場合焦点 $1 \times 1 \mathrm{~mm}^{2}$ を使用）を取付け。

第 1 表 撮影装置・使用用品

$\mathrm{X}$ 線 発生装置 東芝製特型500 $(95 \mathrm{kVp} 3 \mathrm{~mA}$ 連続 $60 \mathrm{kVp} 500 \mathrm{~mA}$ 橓間) 東芝製 $\mathrm{KX}-13(125 \mathrm{kVp} 6 \mathrm{~mA}$ 連続 $60 \mathrm{kVp} 200 \mathrm{~mA}$ 根間)

$\mathrm{X}$ 楾 管 東芝製 DRX-70

(焦点 $1 \times 1 \mathrm{~mm} .2 \times 2 \mathrm{~mm})$ 体芝製 DRX-81 （焦点 $0.3 \times 0.3 \mathrm{~mm} 1.5 \times 1.5 \mathrm{~mm}$ )

断層撮影装置 東芝製 $\mathrm{A}$ 型

多重シャッター 島津製 後藤風雲堂製

フイルムさくら

増 感 紙 東芝製 DS. DH. DD

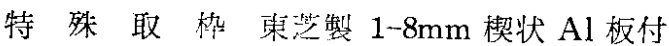

側面用ブッキー 東芒製 (旧型) シェナンデル社製り スホルム,グリッドレシオ $8: 1$

断層用ブッキー 瑓芝製 グリッドレシオ 10:1 
管球は自由に各方向に向けることが出来得るよう改造を 行いました。

KX-13 には DRX-81 を取付け主として高圧抎大撮影 飞使用しました。

DRX-70はX線出射口コーンには外部より観てコーン 疷面内部代 $10 \times 10 \mathrm{~mm}^{2}$ の大きさ以外は厚さ $2 \mathrm{~mm}$ の鉛 を以て覆い，DRX-81 は $5 \times 5 \mathrm{~mm}^{2}$ の大きさ以外を厚さ $3 \mathrm{~mm}$ 鉛を以て覆いました。

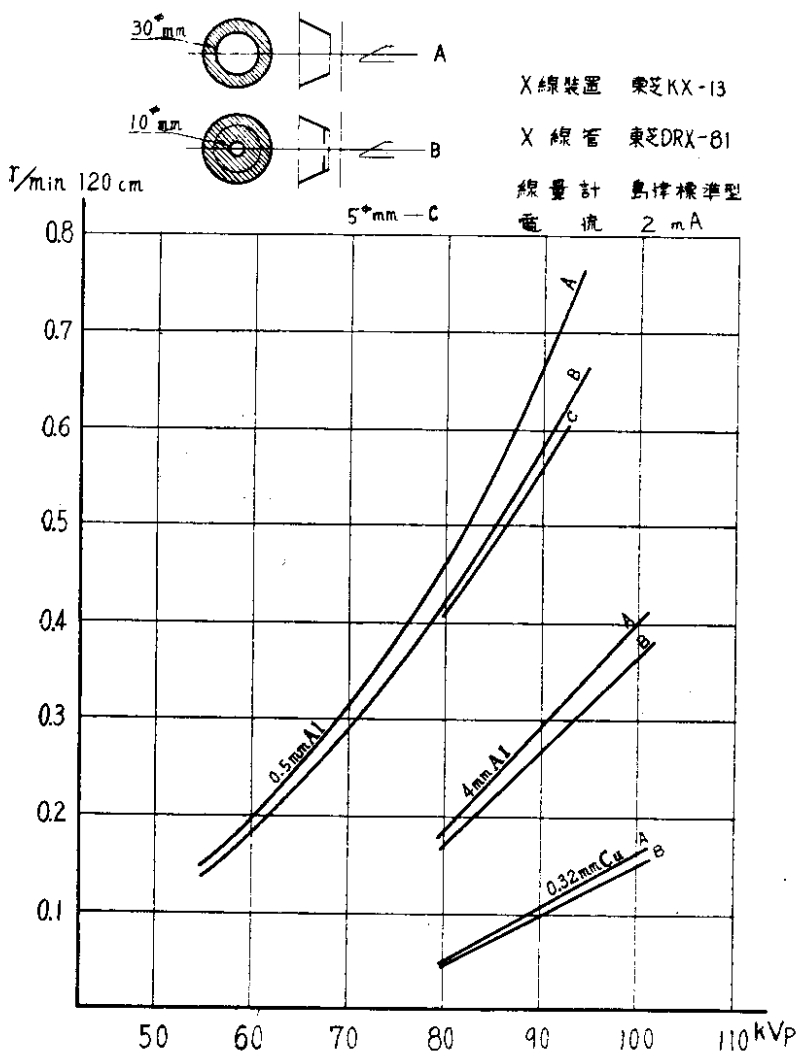

第1図鉛出射孔の変化による線量の変化

この理由は図 1 に示しますように出射ロコーンの内面 侧部に鉛の被覆があり中央正面直径 $30 \mathrm{~mm}$ の部分に鉛が 無いものを $\mathrm{A}$ ，同様に中央直待 $10 \mathrm{~mm}$ の部に鉛力゙無いも のを $\mathrm{B}$ ，同様に中央直径 $5 \mathrm{~mm}$ の部に鉛が無いものを $\mathrm{C}$ としますと，同一濾過板，電圧，電流でも出力線量が異 なります。 $90 \mathrm{kVp} .2 \mathrm{~mA}$. $0.5 \mathrm{mmAl}$ Filter. $120 \mathrm{~cm}$ にお ける $\mathrm{r} / \mathrm{min}$ はAでは 0.66r，Bでは 0.58r，Cでは 0.56r であります。従ってCの出力線量を $100 \%$ としますと B は104\%，Aは118\%であります，Cは焦点以外のX線を も会んでおりますがAは如何に焦点以外のX線が多いか が解り，その線質は第 2 図に示卞如くAはBに比べて半 価層值炒し大きい值を示し線蔶が硬いことを意味して 㧈ります。

焦点以外よりのX線は撮影浪好ましいものでありませ んので出来得る限り乞の発生を防止する意味からしても
鉛出射引の，变伦にSる半価層の变化

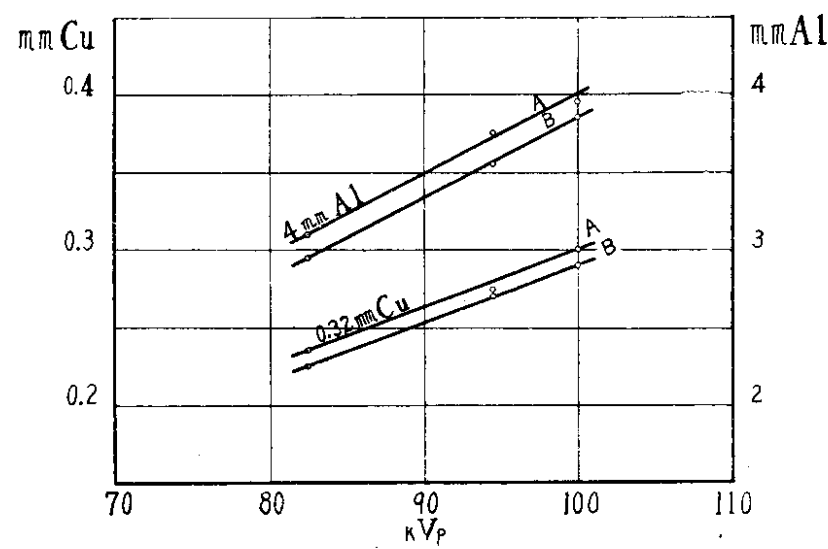

第 2 図 鉛出射孔の変化による半価層の変化

撮影に最小限の鉛出射口を取付ける必要があるのであり ます。

多重シャッターは鉛出射口使用の放射野以内の大きさ の撮影に補所的に使用いたしました。

特殊取枠とは東圤の佐藤秀夫氏の厚意により使用いた したもので，てれは 1 〜 $8 \mathrm{~mm}$ 楔状 $\mathrm{Al}$ 枚付の取枠であり まして濃度差の非常に大きい部位の撮影に使用するもの でありまして感度補償型増感紙では鮮鋭度, 感度比か同 一でありませんがてれは特に鮮鋭度において優れたもの

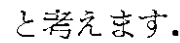

ブッキーブレンデー側面用は東算旧型のラスターを

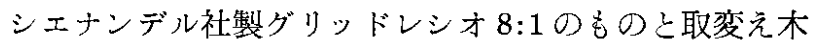
製保持台に取付けた極く簡単なものであります。

厚層断層撮影装置はA 型断層撮影装置の管球運動角度 が最小 30 度なので, それ以下の小角度運動するよう工作 を加えたるのであります。

これは当方で手持部品で組立てたバラックセットで管 球移動角度25度まで可能な電動式のものであります。

写真 1 は側面よりのものでA型断層撮影装置への連結 状態を示し簢単に取りはずし出来る構造のものでありま

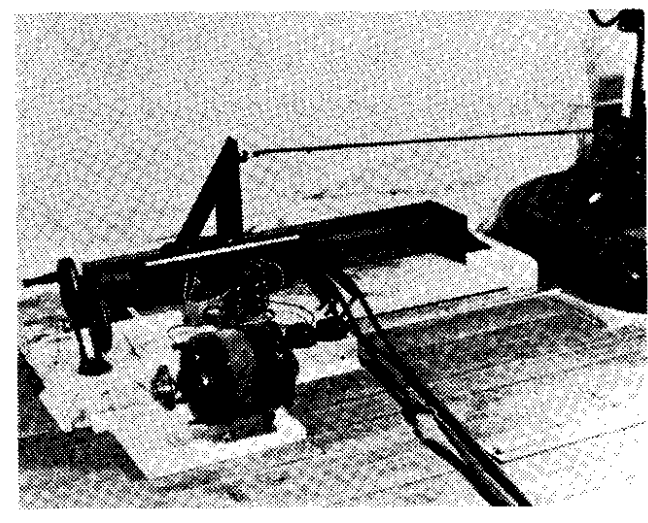

写真 1 断層装置八連結した小角度制辝部 


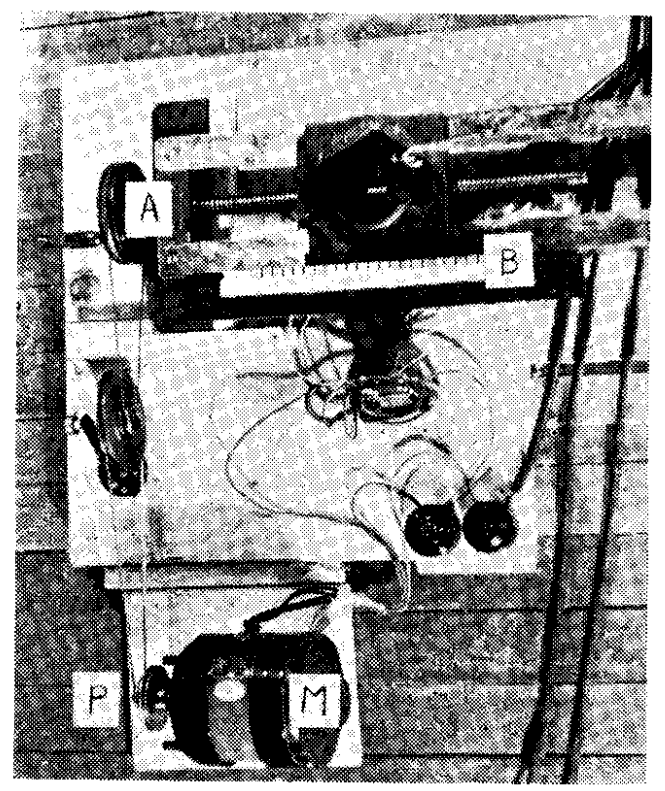

写真 $2 M$ モーター

$\mathrm{P}$ 三段プーリ

A 微動装置

B 管球移動角度スケール

す。写真2は上部よりのものでMは1仗馬力の単相誘導電 動機, その备転軸には 3 段プーリか取付けてあります。

Aは球間嚐電在測定器に使用していた微動装置を転用 し，BはX線管移動角度を目盛ったスケール，その下に 2 個のマイクロ・スイッチが取付けてあり志す.

動作はブッキーブレンデーが始動し次にモーターが涃 転し X線管が移動し X線を放射し一定角度に達するとX 線管回路方自動的に開路しモーターも止ります.

\section{呼吸時㵊影法}

正面撮影時は四吸時撮影の重要性は認めません，刖部 の厚さが非常に差肪ある場合通常胸椎上部は濃度が高く 下部胸椎は濃度が低くその差が極端と洘えられる場合補 沿フイルターまたは特殊取枠楔状 $\mathrm{Al}$ 板付のものを使用 しますと観察し易いラチチュードの富んだものが得られ ます(写真 3 )。

成人上部胸椎正面の重覺しない即ち椎間を正しく撮影 するには約 20 度足方に管球を傾斜する必要があります。

㸝椎正面は通常 $1 \mathrm{~m}$ 撮影, 増感紙は DD 級の高解像力 のものを使用します。

写真 4 は㭔吸時撮影の側面時の一体位を示し呼吸によ る体動摇安劣慮した安定な体位の1例です，雨上肢は頭 上に組ませるか, 上方に伸ばすか, 腹部に組ませ出来得 る限り雇胛骨が上膊骨と重畳しないように静かに，穏や 內なやや淡い呼吸を行なわせます。

撮影距離は $1 \sim 1.5 \mathrm{~m}$, 増感紙は $\mathrm{DD} \cdot \mathrm{DH}$ 級を使用し 第 4 胸椎以下を対象とします。

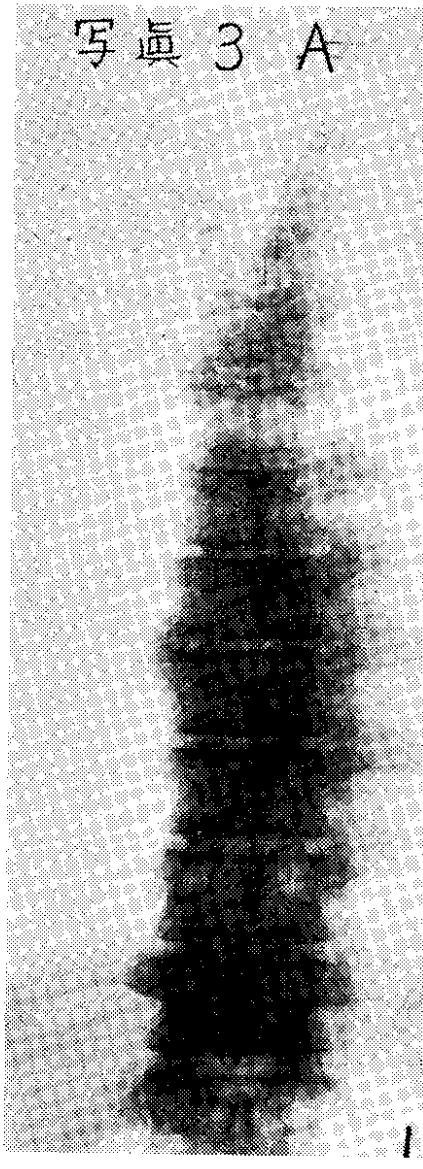

写真 $3 A$ 特殊取枠使用 上 部 $8 \mathrm{~mm}$. 下部 $1 \mathrm{~mm}$ 楔状 $\mathrm{Al}$ 板

\begin{tabular}{|c|c|c|}
\hline & 8 种 & $\mathrm{DD}$ \\
\hline & t & $23 \mathrm{~cm}$ \\
\hline 電 & 圧 & $74 \mathrm{kVp}$ \\
\hline & 流 & $100 \mathrm{~mA}$ \\
\hline & 間 & $1 \mathrm{sec}$ \\
\hline & 两 & $100 \mathrm{~cm}$ \\
\hline
\end{tabular}

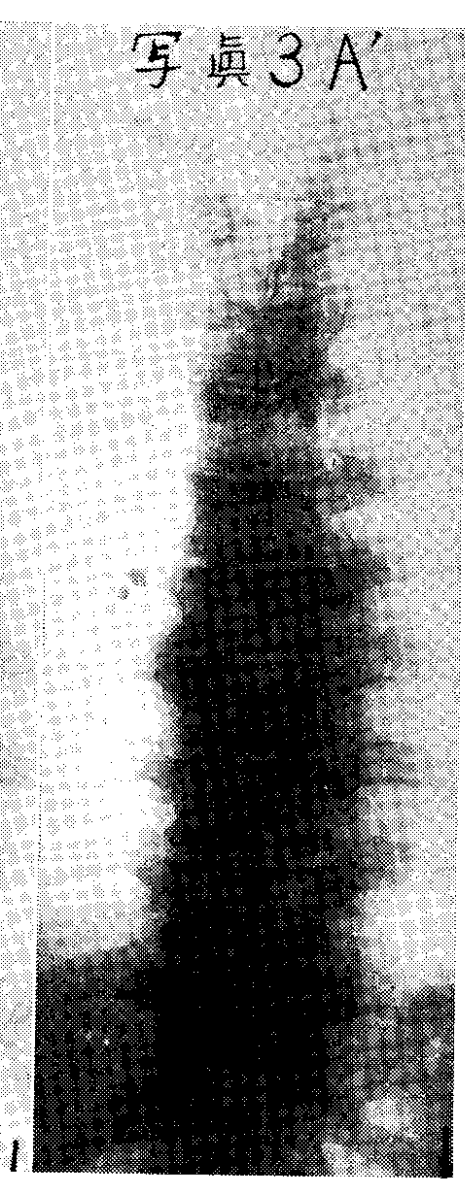

写真 $3 A^{\prime}$ 普通取枠使用 増感紙 DD 被写体嘎さ

$\begin{array}{lll} & & 23 \mathrm{~cm} \\ \text { 電 } & \text { 圧 } & 74 \mathrm{kVp} \\ \text { 電 } & \text { 流 } & 100 \mathrm{~mA} \\ \text { 時 } & \text { 間 } & 1 \mathrm{sec} \\ \text { 距 } & \text { 離 } & 100 \mathrm{~cm}\end{array}$

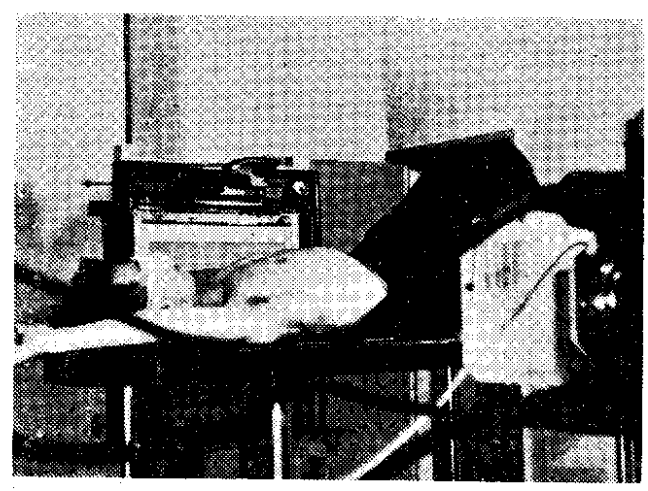

写真4 乎吸時胸椎㑡面撮影体位の 1 例

撮影時間は一呼吸より短かいものでは意味が無く，ま たあまり長時間も体動摇の恐れがあるので通常４－10秒 程度といたします。

写真 5 は同一人の呼吸時と停止時の直接撮影の此較, 


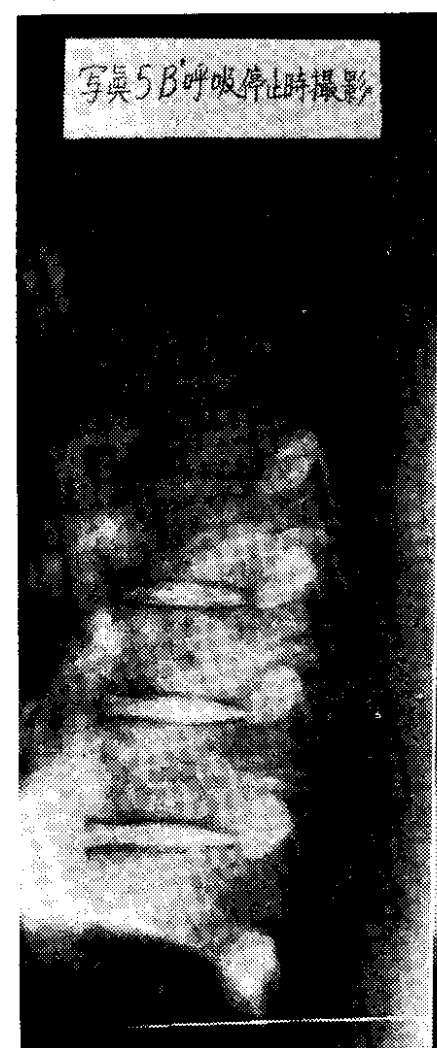

写真 $5 \mathrm{~B}$ 呼吸停止㭙撮影 $70 \mathrm{kVp} .50 \mathrm{~mA}$. 8sec. DD

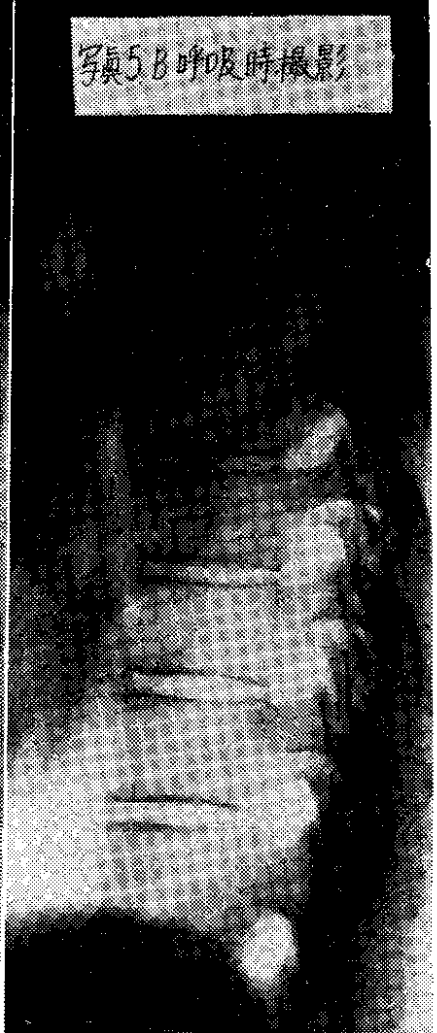

写真 $5 B^{\prime}$ 呼吸時撮影 $70 \mathrm{kVp} .50 \mathrm{~mA}$ 8 sec. $150 \mathrm{~cm}$.DD

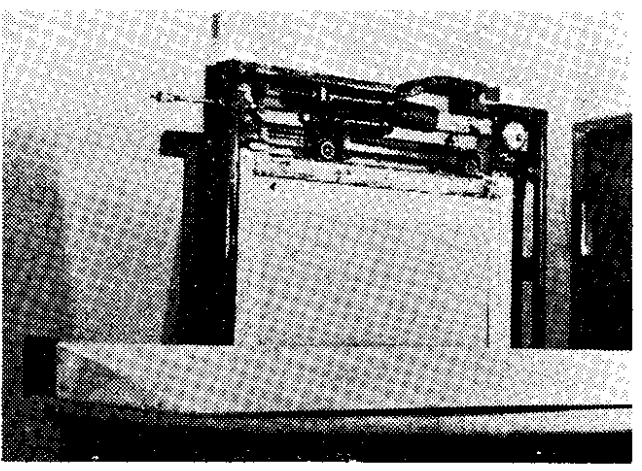

写真 710 度斜位撮影用補助用具

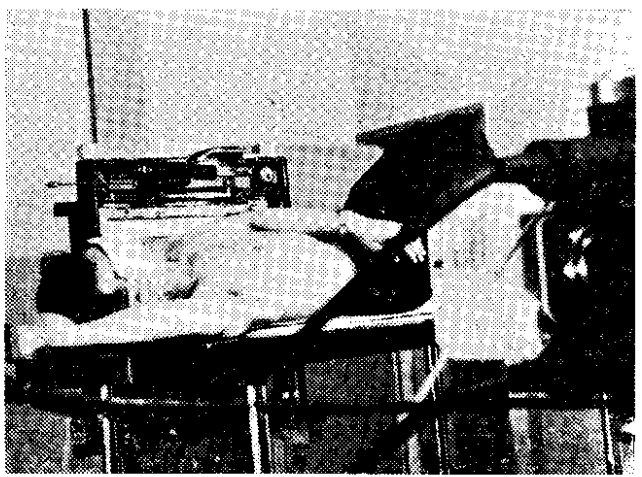

写真 8 上部胸椎 10 度斜位撮影洔の体位

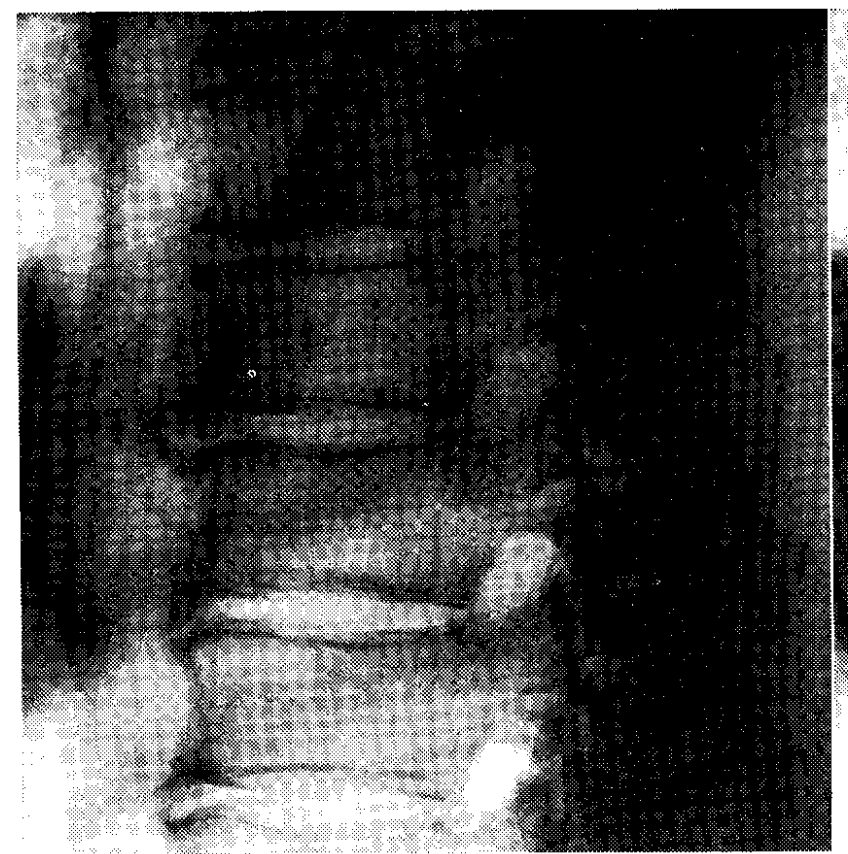

写真 6 高圧拡大写真 (2 倍) C

呼吸時撮影 $110 \mathrm{kVp}$. $5 \mathrm{~mA} .8 \mathrm{sec}$

焦点梏間距離 $50 \mathrm{~cm}$ 焦点フイルム間距離 $100 \mathrm{~cm}$ 離增感紙 $\mathrm{DD}$

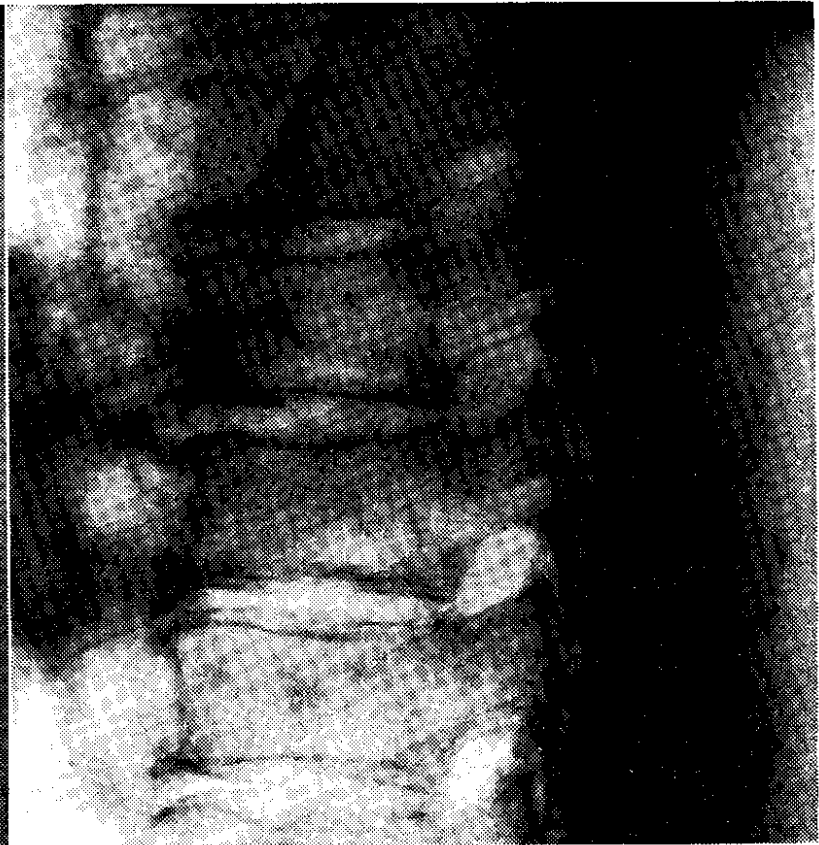

写真 6 高圧抬大写真 ( 2 倍) $\mathrm{C}^{\prime}$

泘吸停生時撮影 $110 \mathrm{kVp} .5 \mathrm{~mA} .8 \mathrm{sec}$

焦点胸椎間距離 $50 \mathrm{~cm}$ 焦点フイルム間距離 $100 \mathrm{~cm}$ 增 感 紙 DD 


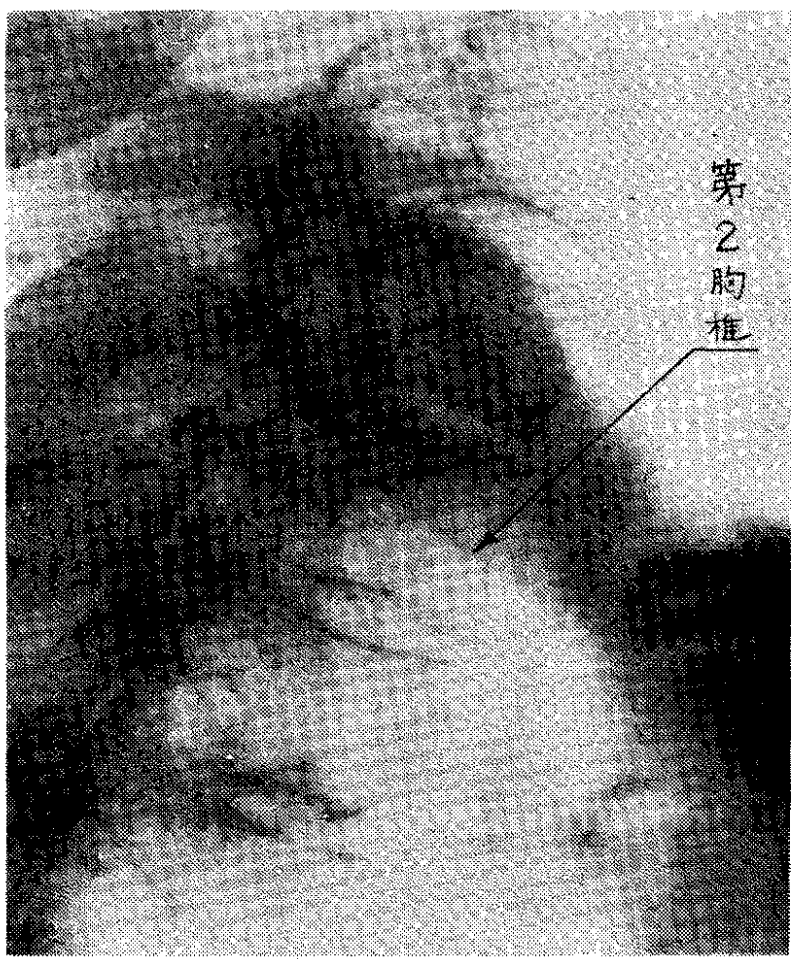

写真910度斜值抬大写真

$\begin{array}{ll}\text { 呼吸時撮影 } & 110 \mathrm{kVp} .5 \mathrm{~mA} .8 \mathrm{sec} \\ \text { 焦点胸椎間距離 } & 50 \mathrm{~cm} \\ \text { 焦点フイルムム間距離 } & 100 \mathrm{~cm} \\ \text { 増感紙 } & \text { D.D }\end{array}$

写真 6 注同一人の呼吸時已停止時の高压拡大（2倍）撮

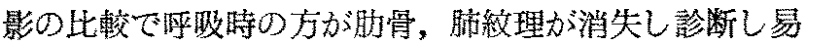
w.

军真 7 は10度斜位撮影のための整定的な補肳用具でベ 二ヤ板で製作し撮影台に10度の傾斜を有し撮影部位の上 る部分は唋を使用しておりません。

写真 8 は上部胸椎 10 度斜位撮影時の体位であります。 これは撮影台上に10度斜代の中空べニヤ箱を乘せをの上 亿被写体加上り主す。

入射X線側の上肢は頭上万句に伸ばすか，または则劣

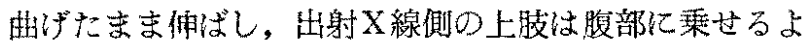
らにします。人射X線中心掖下の横やや前胸部より第

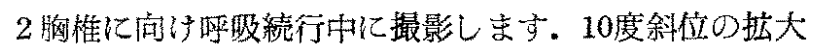
撮影は多重シャッターを利かせブッキーブレンデーは使 用いたし字をん。

写東 9 は呼吸時々停此時の2 倍高圧搪大写真ですが胸

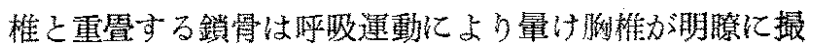
影され呼吸時撮影力優れております。

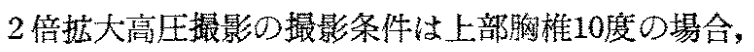
焦点胸椎間 $50 \mathrm{~cm}$ ，胸椎フィルム間距離 $50 \mathrm{~cm}$ 。電圧は $100 \sim 120 \mathrm{kVp}$. 電流 $5 \mathrm{~mA}$. 時間 4 -8sec. 增感紙住 DD*

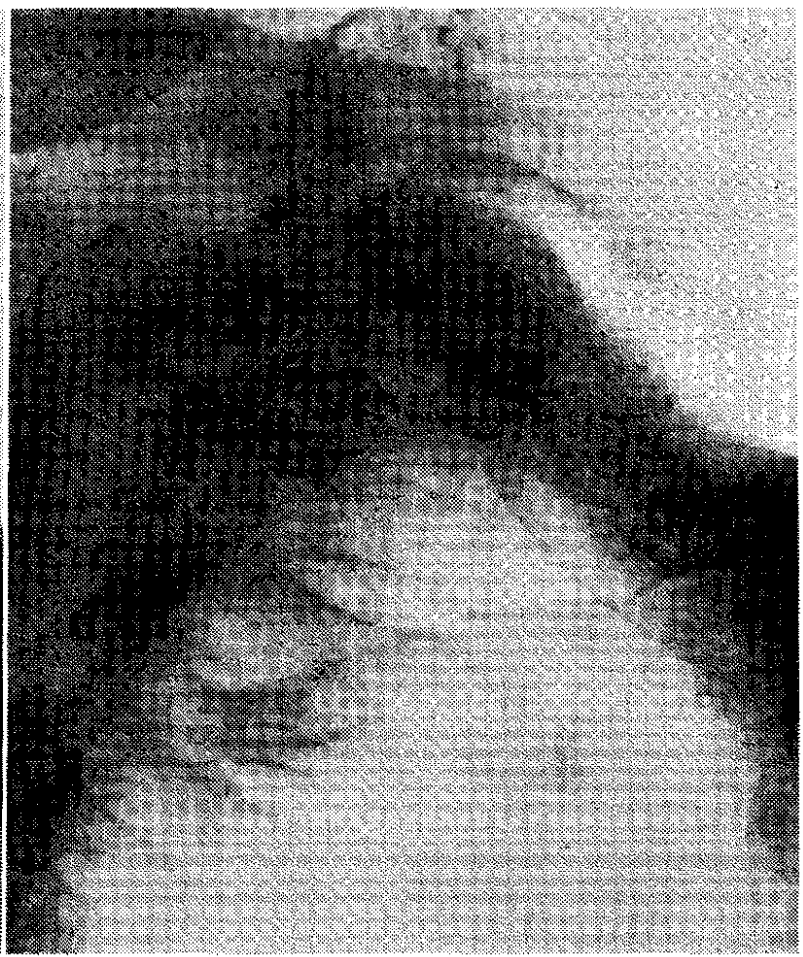

军真 910 度斜位玟大写真

$\begin{array}{ll}\text { 呼吸停止特撮影 } & 110 \mathrm{kVp} .5 \mathrm{~mA} .8 \mathrm{sec} \\ \text { 焦点胸椎閵距離 } & 50 \mathrm{~cm} \\ \text { 焦点フイルムム間距離 } & 100 \mathrm{~cm} \\ \text { 增感紙 } & \text { D.D }\end{array}$

DH 級を使用します。

\section{断雷摄影装是による㫗首攝影法}

従来の断風撮影の如く数枚の撮影フィルムに上り観察 するのではなく，1枚のフィルムで角度の管球移動に より相当厚い部位を比較的鮮鋭に現出させ直接撮影の代 りてするといら替方方であります。

表 3 は管球移動角度とズレ $\alpha$ の関䋆を示し焦点の大き き，増感絟，フィルム入射角のボケ等は全々洘慮しない 埸合でありまず.管球移動角度 2.5 度でも断面より $1 \mathrm{~cm}$

第 3 表 $\alpha$

\begin{tabular}{|c|c|c|c|c|c|c|c|}
\hline$\gamma$ & 1 & 2 & 2.5 & 3 & 5 & 10 & 15 \\
\hline $1^{\circ} 15^{\prime}$ & 0.06 & 0.11 & 0.14 & 0.17 & 0.29 & 0.61 & 0.97 \\
\hline $2^{\circ} 30^{\prime}$ & 0.11 & 0.23 & 0.28 & 0.34 & 0.58 & 1.22 & 1.94 \\
\hline $5^{\circ} 00^{\prime}$ & 0.22 & 0.45 & 0.57 & 0.69 & 1.16 & 2.45 & 3.88 \\
\hline $10^{\circ} 00^{\prime}$ & 0.45 & 0.91 & 1.14 & 1.38 & 2.35 & 4.95 & 7.84 \\
\hline & & $\frac{2 y \sin }{R \cos \theta}$ & \multicolumn{5}{|c|}{ 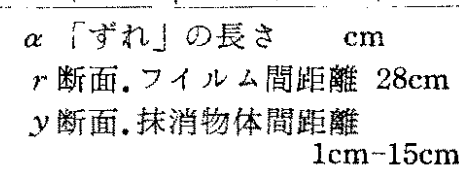 } \\
\hline
\end{tabular}

$R$ 断面。焦点間距離 $105 \mathrm{~cm}$

$\theta$ 運動角度の1/2 $1^{\circ} 15^{\prime}-10^{\circ} 00^{\prime}$ 


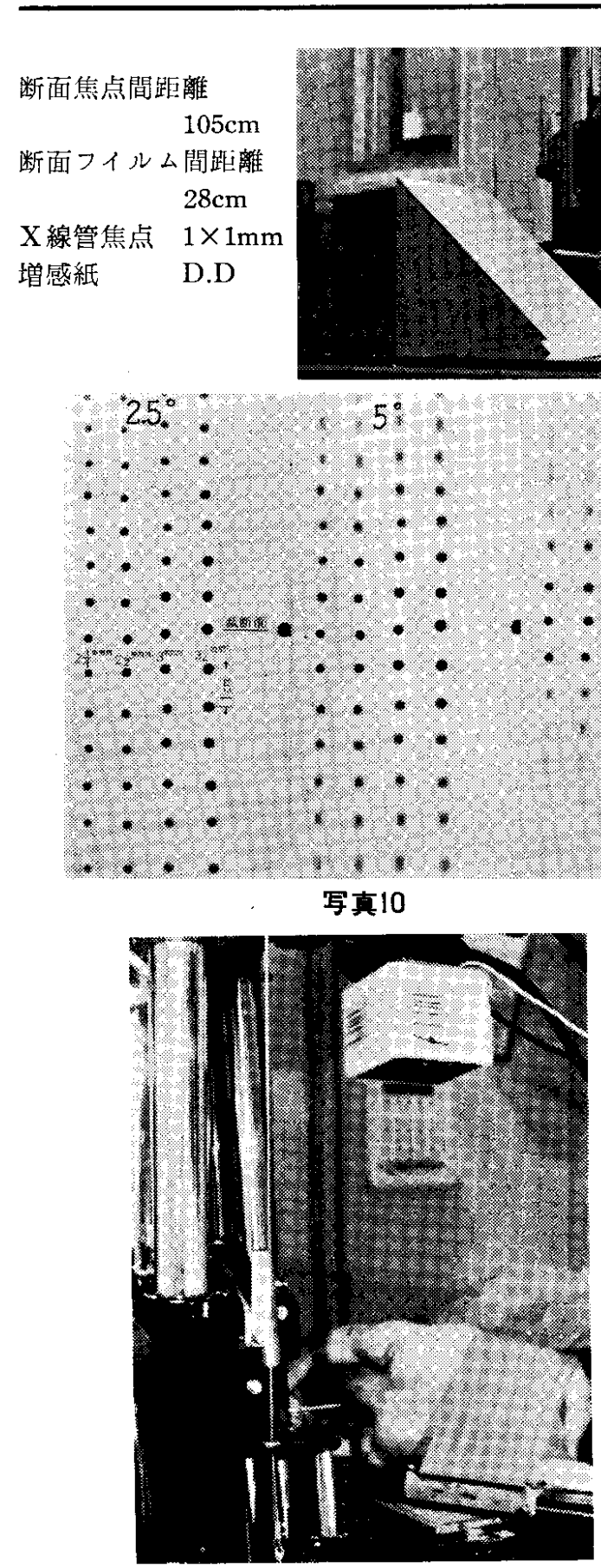

写真11 上部胸椎の厚層撮影体位

離れた部位のボケは $0.6 \mathrm{~mm}$ で冬眼的にもボケとして認 め得るものであります。

写真10は45度傾斜の中空ベニヤ箱の 45 度斜面に高さ 1 $\mathrm{cm}$ 間隔に直径 $2 \frac{1}{4} \cdot 2 \frac{1}{2} \cdot 3 \cdot 3 \frac{1}{4} \mathrm{~mm}$ の鉛散弾を置き断 面フィルム間距離 $28 \mathrm{~cm}$. 断面焦点間距離 $105 \mathrm{~cm}$. X線 管焦点 $1 \times 1 \mathrm{~mm}^{2}$ ． 増感紙 DD. さくらフィルムで管球 移動角度 $2.5^{\circ} .5^{\circ} .10^{\circ}$ で撮影されたもので移動角度に対 する撮影部位の大体の範囲を識ることが出来ます。

写真11は上部胸椎の厚層撮影体位で雨下肢は㯟を曲げ, 両上肢は上方に伸ばすか頭上で組ませ，頸椎，胸椎，腰

$$
\begin{aligned}
& \text { 马豪 } 12 \\
& \left.90^{\mathrm{KP}} 100^{\mathrm{mA}}\right|^{\mathrm{acc}} 130^{\mathrm{cm}} \\
& \text { D. D }
\end{aligned}
$$

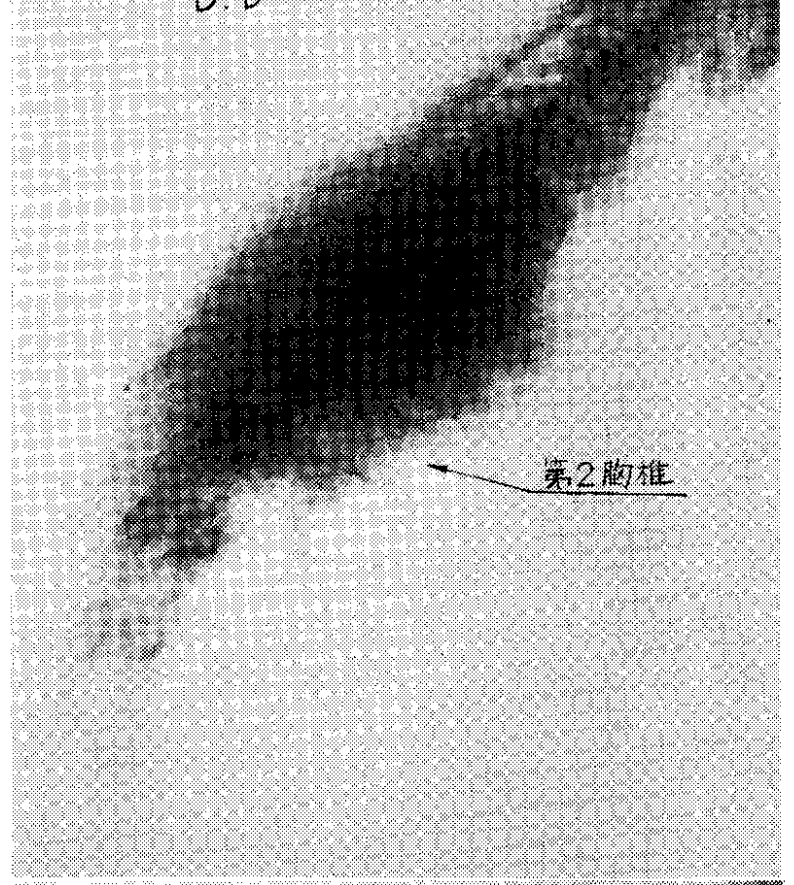

写魚 12

椎上部の中心か撮影台面と平行となるよう補肋パッキン グ (スポンジゴム, 布, 綿等) を入れ胸部は固定帶で固 定します。 


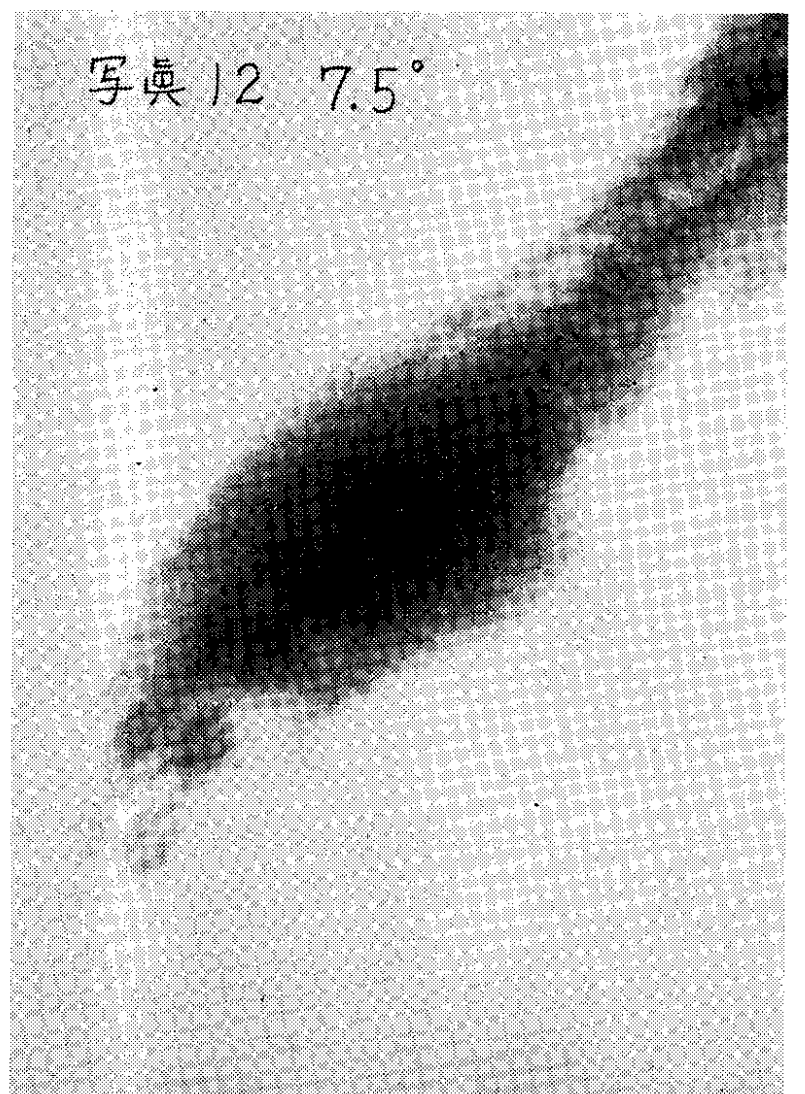

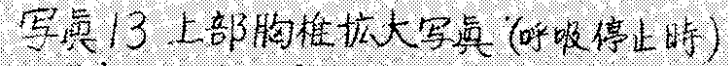

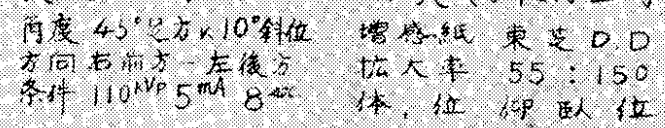

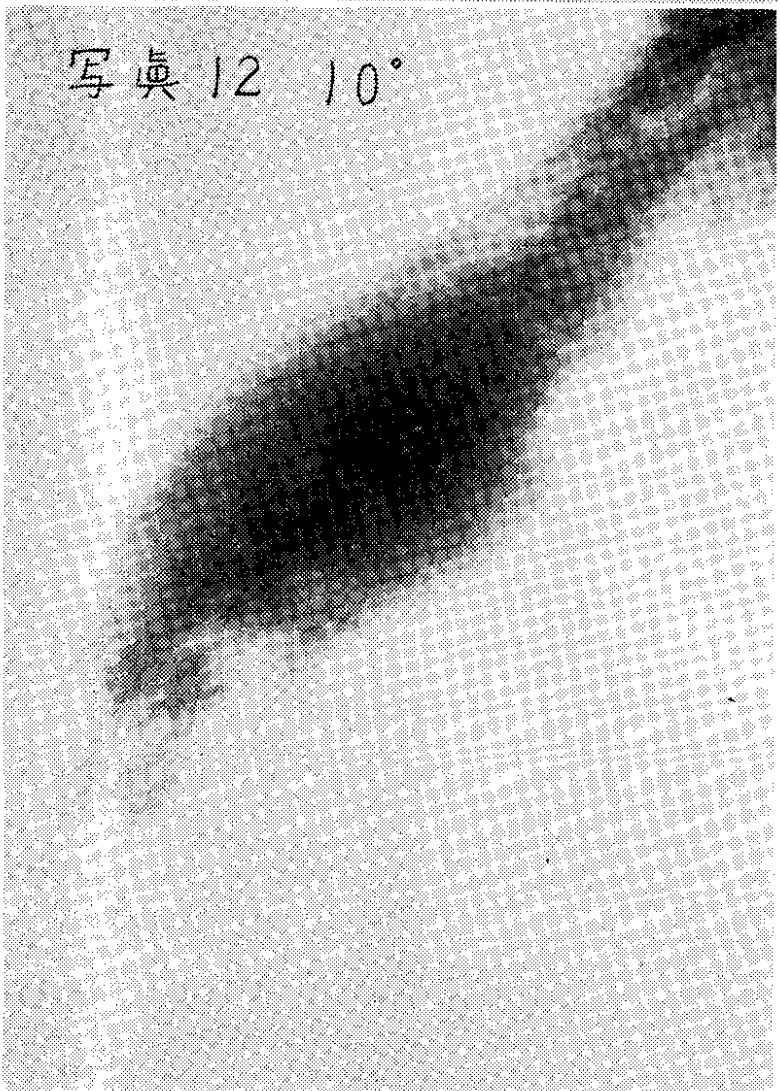

(写真は断面を指示するため固定带の位置を上腹部にし てあり志すが実際は胸部にいたします。)

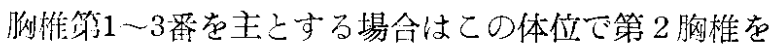
角度で運動させ呼吸停止時動摇の無いように撮影を行う のであります. 


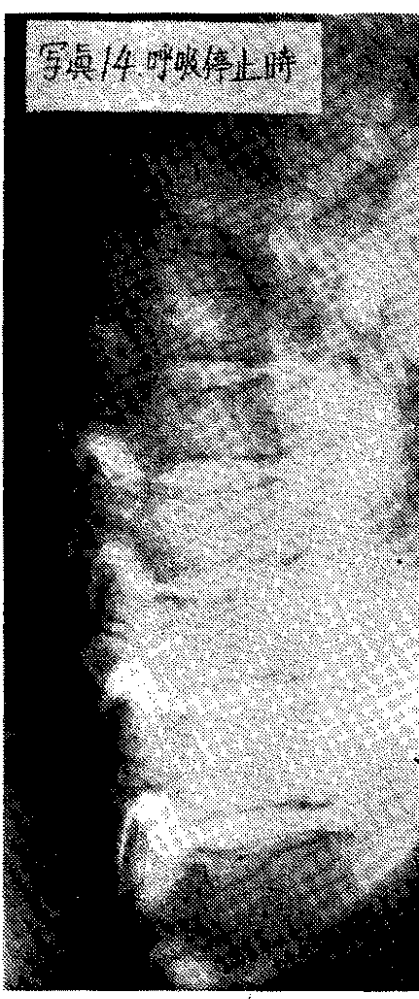

写真 14 呼吸停止時 $75 \mathrm{kVp}, 100 \mathrm{~mA} .1 \mathrm{sec}$. $130 \mathrm{~cm}$. DD

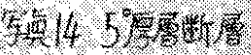
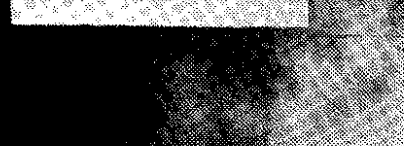

(2)

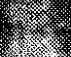

(3) (x)

S
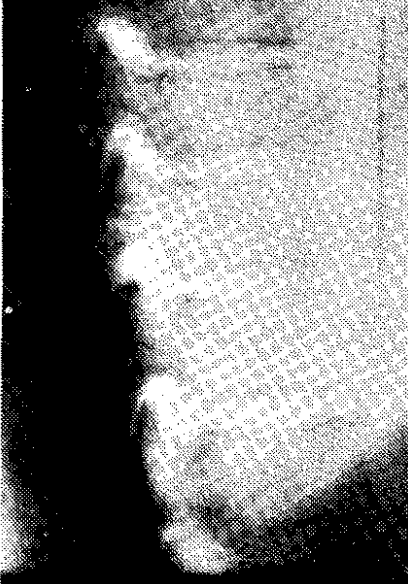

写真14 $55^{\circ}$ 厚周断尿 但し管球体軸に対し平行 $75 \mathrm{kVp} .100 \mathrm{~mA}$. $1 \mathrm{sec}$. $130 \mathrm{~cm}$. DD

写真12右上野已病的㓌影のある結核患者古右左側方 向で2.5度，5度，7.5度，10度で撮影をしたものでありま

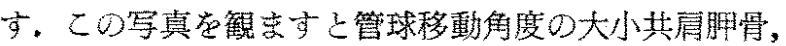
肋骨は消失し，角度の大なるはど鎖骨の消失の程度が大

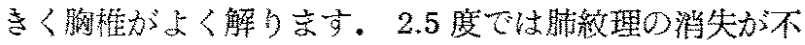
充分で，佮度の大なるほど胸椎は一見直接撮影ようの像 子り従来○略圈像に移行します。

小角度による胸椎側面攝影時は 2.5 度一 5 度, 第 1 - 3 胸 椎撮影時路 5 度を使用いたします。

撮影条件 第 1 -3胸椎側面時, 電圧 $70 \sim 90 \mathrm{kVp}$. 電流 $100 \mathrm{~mA}$. 時間 $1 \sim 2 \mathrm{sec}$, 断面焦点踓離 $105 \mathrm{~cm}$. 增感紙は DD. DH. DS を被写体の愿さに応じて使用し出来得る 限り側期位であるため体動㜔の無いように長時間撮影を 行なわ双ようにいたしまず。

\section{考察}

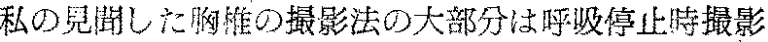

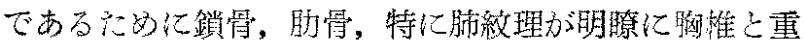

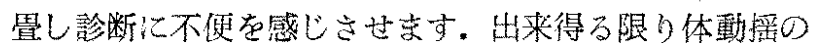

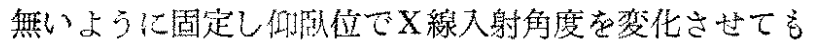
フィルム面に垂直に入射するような工夫をし，静かに，

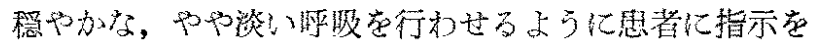

しで数回練習を行わせ外観的にも胸椎の動摇が無いと確

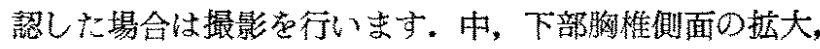
直接撮影を呼吸時, 停止時に行い呼吸時の約 $80 \%$ は停止

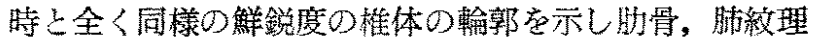
ははぼ消失し䧐新的に飛躍的結果を示しました。

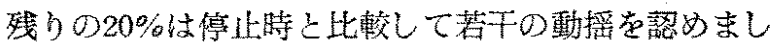
たが従来の大焦点撮影と比䡥する場合許容され得る程度

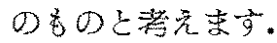

撮影前の予備練習で注意を与えても呼吸により碩部, 顽部，特に上胸部门背部を動摇させる患者多くは年少者 及び婦女子の一部讨期待ずべきでなく停止時撮影を行う ベきであります.

上部胸椎の㑡面撮影こして Barsong 氏法が提陧され ておりますが診断的価值ある写真を得るてとはなかなか 困難でそれと代って斜位撮影力行なわれておりますが， 出来得る限り側面に近いるのが要望されております。

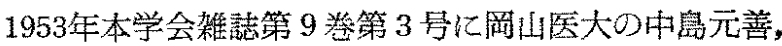
江沢尊之画氏は入射角度 10 度で側卧位を提唱されており，

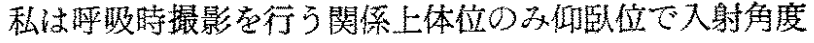
10度を以て現在特に高圧拡大撮影を行っております。

この撮影法では㭔吸により鎖罗が暈け胸椎は明膫に描

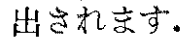

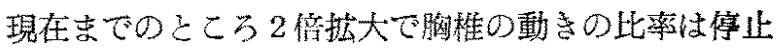
時の約 $68 \%$ であまり良好な成績ではありませんが，てれ

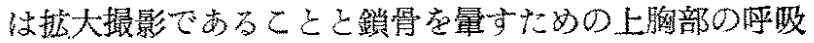
運動か体動摇の原因となっていると考えられますが，患 者数が少小いので今挠の観察方泌要と思い寸す。

断層撮影装置による小角度厚首撮影は方法々観祭者の 主観による满足の程度によって洒做が決ることと思いま すが，小焦点で呼吸時撮影によるものと比較しては及ぶ ものではすり志はん。これは如何に一見良好に撮影され たものでも筒梁，榆郭を詳細に観察するならば，断面よ り隔れるに徤い明紐度が低下し直接穝影の代用とはなり ま过んでした。

この撮影法の最亏期待されるのは胸椎第 1 第 3 胸椎 の側面撮影であり銧骨は管球運動により暈け胸椎は現出 しまする制約された管球移動角度内においては鎖骨の量 けを少しです大きくするたか管球移動方问を決定すべ

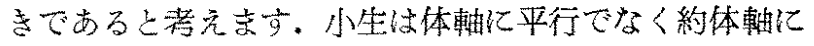
30 度り方向に5度り管球移動角度を採用しましたが今後

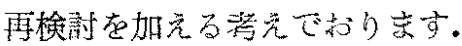

\section{結論}

1) 呼财時撮影は雭者に指示を理解してもらって実行 
するならば優れた診断価值の高い写真が得られます。

2）断首撮影装置による厚層撮影は上部胸椎の側面撮 影に適した方法であります。

終りに臨み発表の機会を与えられた青木会長，種々御 批判と御便宜を計られた当病院整形外科医長大吉清先生, 文献の御提供と御批判を戴いた札幌聥信療養所 草皆太 平君, 美唄学多病院 河崎米次郎君, 特殊取枠を御借し 下さった東芝 佐藤秀夫氏，実験に協力戴いた当病院 三谷幸男君，原子昭一君，垂水宗司君に淡く感謝いたし ます。
交献

1) K. C. Clark ; Positioning in Radiography. London Ilford dim. 1949.

2) G. Gurreiro ; "Lateral Roentgenographic Examination of the Thoracix Spine". The Jaunal of Bane and Joint Suzery 1950 Jan.

3）草皆太平；胸椎側面及犬胸骨のX線撮影法について。 日本放射線技知学会雑誌，Vol. 7，No. 4. 1952.

4）浦山晴一; 胸椎側方 X線像に対する原首撮影の経験. 整形外科, Vol. 8, No. 4. 195.

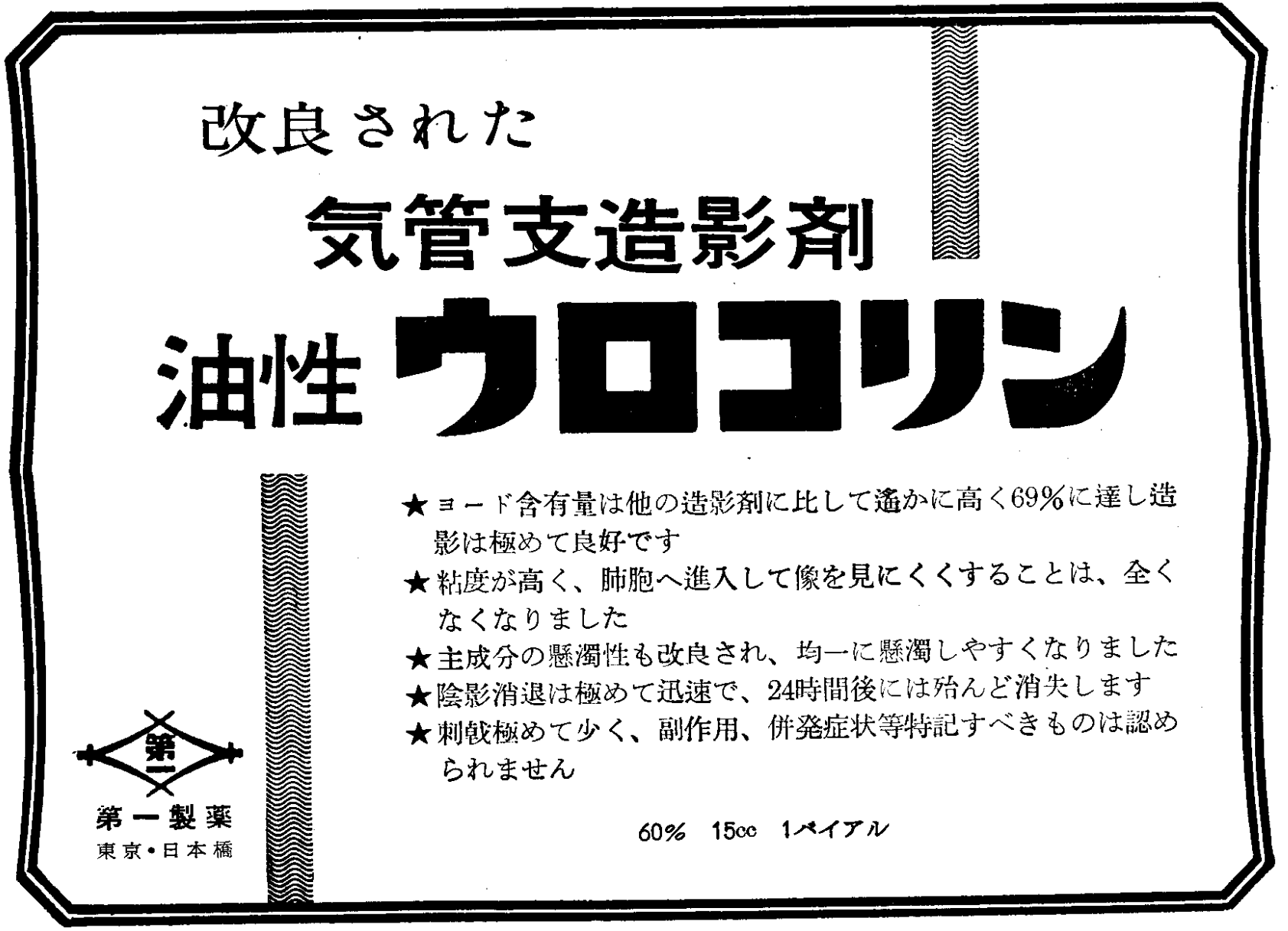

